\title{
Concerns regarding hepatitis $B$ vaccination and post-vaccination test among Brazilian dentists
}

\author{
Vera Lúcia S Resende ${ }^{\dagger 1}$, Mauro Henrique G Abreu², Saul M Paiva ${ }^{*+3}$, Rosângela Teixeira ${ }^{\dagger 4}$ and Isabela A Pordeus ${ }^{\dagger 3}$
}

\begin{abstract}
Background: Hepatitis B infection is the major cause of acute and chronic liver disease, cirrhosis and hepatocellular carcinoma worldwide and has long been recognized as an occupational hazard among dentists. The aim of the present study was to examine factors associated to the self-reporting of hepatitis B vaccination and immunization status among dentists working in the city of Belo Horizonte, Brazil.

Methods: A cross-sectional survey was carried out with 1302 dentists in Belo Horizonte, Brazil. After signing a term of informed consent, the participants answered a structured questionnaire on their knowledge regarding their vaccination and immunization status against hepatitis B. Data on demographic, behavioural and occupational exposure aspects were also collected through questionnaires.

Results: The results revealed that $73.8 \%$ of the dentists reported having received three doses of the vaccine. Multivariate analysis revealed that gender ( $p=0.006)$, use of individual protective equipment $(p=0.021)$, history of blood transfusion ( $p=0.024)$ and history of illicit drug use $(p=0.013)$ were independently associated with vaccination against hepatitis B. Only $14.8 \%$ had performed a post-vaccination test. The use of individual protective equipment $(p=$ 0.038 ), dentists who asked patients about hepatitis during dental treatment $(p<0.001)$, a family history of hepatitis $B$ ( $p$ $=0.003)$ and work experience $(p<0.05)$ were independently associated with the post-vaccination test.
\end{abstract}

Conclusions: Although there were a large number of vaccinated dentists in Belo Horizonte, the percentage was less than what was expected, as Brazil offers the National Program of Viral Hepatitis Vaccination, which provides free hepatitis B vaccinations to all healthcare workers. Despite being part of a high risk group for contamination, most of the dentists did not know their immunization status.

\section{Background}

Hepatitis B virus (HBV) is the major cause of acute and chronic liver disease, cirrhosis and hepatocellular carcinoma worldwide and has long been recognized as an occupational hazard among dentists [1-6]. A third of the world population (two billion people) has evidence of hepatitis exposure and an estimated 400 million are actively infected $[3,7]$. HBV is one of the major diseases of mankind and is a serious global public health problem $[8,9]$. HBV is transmitted primarily through parenteral and sexual exposure to HBsAg-positive blood or other body fluids from individuals who are chronic HBV carriers or have acute hepatitis B [2]. These chronically

\footnotetext{
*Correspondence: smpaiva@uol.com.br

3 Department of Paediatric Dentistry and Orthodontics, Dental School, Federal University of Minas Gerais, Belo Horizonte, Brazil

+ Contributed equally

Full list of author information is available at the end of the article
}

infected individuals are at high risk of death from cirrhosis of the liver and liver cancer, diseases that kill about one million people each year $[10,11]$.

As the dental profession involves the use of small, sharp instruments contaminated with blood or other fluids, there is ample opportunity for inadvertent skin wounds to the operator and staff $[1,2,12]$. Such accidents include the possibility of transmission of hepatitis $\mathrm{B}$, hepatitis $\mathrm{C}$ and human immunodeficiency virus (HIV) [13]. To decrease the risk of $\mathrm{HBV}$ infection, it is recommended that dental personnel receive immunization against HBV and use individual protective equipment, such as gloves, to prevent blood-borne infection during dental procedures $[1,11]$.

The hepatitis B vaccine has been available since 1982 and, since 1990, has been recommended for healthcare workers whose activities frequently expose them to blood $[7,10,11,14]$. However, 5 to $10 \%$ of normal subjects do not 
produce the anti-hepatitis B surface antibody (anti-HBs) after receiving a standard course of HBV vaccine $[7,15,16]$. Thus, post-vaccination testing one to three months following the third dose of vaccine is recommended for healthcare workers who have contact with blood [7]. Previous studies carried out in other countries have revealed different proportions of self-reported vaccination, ranging from $40.3 \%$ to $97.0 \%$ [17-23]. The proportion of dentists who have had their antibody titer evaluated ranges from $36.5 \%$ to $47.9 \%$ [20,21]. In Brazil, one study found that only $73.1 \%$ of dentists had been submitted to the three doses of the vaccine [24].

There is little information on factors associated to adherence to the vaccination and the evaluation of immunization status regarding hepatitis $\mathrm{B}$ among dentists. The aim of the present study was to examine factors associated to the self-reporting of hepatitis B vaccination and immunization status among dentists working in the city of Belo Horizonte, Brazil.

\section{Methods}

This is a cross-sectional study nested in a larger study assessing factors associated to the seroprevalence of hepatitis $\mathrm{C}$ among dentists in the city of Belo Horizonte, Brazil. The dentists were first contacted, enrolled and invited to take part in the study in November 2004, when all dentists registered at the Minas Gerais Dental Council were required to elect the administrative board of the council. Belo Horizonte is the capital of the state of Minas Gerais and is an industrialized city with about 2.4 million inhabitants. The sample size was calculated to give a $95 \%$ confidence interval, $0.75 \%$ precision level [25] and using a $3 \%$ prevalence of hepatitis C [10]. The inclusion criteria were dentists living and working in the city of Belo Horizonte and registered at the Minas Gerais Dental Council. This group consists of a finite population of 2766 dentists. The minimal sample size to satisfy the requirements was estimated as 1156 dentists. Taking into account the possibility of losses, a correction factor of 1.2 was adopted, totalling an expected sample size of 1387 dentists. These dentists scheduled a visit at the clinical analysis laboratory of the Medical School of the Federal University of Minas Gerais. A total sample of 1302 dentists (response rate $=93.9 \%$ ) answered the questionnaire between December 2004 and June 2006. The sampling strategy is detailed in a previous article [26]. All participants signed a term of informed consent and data were collected on demographic, behavioural and occupational exposure aspects.

\section{Questionnaire}

A self-administered questionnaire consisting of twenty open-ended and close-ended items was used for the data collection. The drafting of this questionnaire complied with all steps proposed by previous studies $[27,28]$. Once the purpose of the study and its conceptual basis were defined, the drafting of the items was carried out by means of a broad-based review of the literature [29-32]. Content validation was performed to determine the suitability of the theoretical content and functionality of the questionnaire. Item selection, adaptation and additional inclusions were then performed based on the opinion of an expert in research and marketing. An opinion was subsequently formed by a commission made up of professionals from different dental institutions and specialties. Unanimity in the approval of the questionnaire was required for validation. Suggestions for changes were heeded when brought up repeatedly by different commission members. Response options were organized vertically. All survey items were constructed in the same format in order to avoid placing emphasis on any specific item [26].

In the present study, the following variables were taken into account:

\section{1-Personal and behavioural data}

Gender; sexual behaviour (unprotected homo/hetero sex with a casual partner); blood transfusion; previous history of hepatitis in participant or family member; and use of illicit injection drugs. Since the latter variable is quite sensitive, this point was addressed in combination with exposure factors, such as the use of piercing and tattoos, history of any kind of transplant, dialysis, colonoscopy and chemotherapy.

\section{2-Professional, behavioural and occupational exposure data}

Work experience; workplace; field of work; use of individual protective equipment (IPE); vaccination for hepatitis $\mathrm{B}$; immunization against hepatitis B; history and number of needle stick accidents with visible bleeding; dental assistance for patients with hepatitis; and whether the dentists' clinical dental chart contains a question on a history of hepatitis.

As individuals may go to school at any time in their lives and the number of years of professional activity may be more important than age in representing exposure to risk factors, the age of the participants was not inquired, but rather the duration of activity (work experience). To analyze the influence of work experience, the sample was categorized into four groups: less than 10 years; 10 to 20 years; 21 to 30 years; and 30 years or more. The workplace was considered public, private or both.

Data were analyzed using the Statistical Package for the Social Sciences (SPSS for Windows, version 17.0, SPSS Inc, Chicago, IL, USA). Bivariate analysis was the initial analytic strategy (Fisher's exact test and Pearson's chisquare test). Multivariate Poisson regression with robust variance was then performed. Vaccination for hepatitis $B$ and immunization against hepatitis $B$ were the dependent variables. The level of significance was set at $\alpha=0.05$. 


\section{Results}

Among the total number of dentists surveyed, $87.1 \%(\mathrm{n}=$ 1134) answered the question on hepatitis $B$ vaccination and $74.8 \%(\mathrm{n}=974)$ answered the question on immunization for hepatitis B. Among the study sample $(\mathrm{n}=1302)$, $73.9 \%$ reported having received the three doses of the vaccine. There was an association between vaccination against hepatitis $B$ and gender $(p=0.003)$, use of IPE $(p=$ $0.001)$, blood transfusion $(\mathrm{p}=0.006)$ and combined factors $(\mathrm{p}=0.026)$ in the univariate analysis (Table 1$)$. The multivariate analysis revealed that women had a 1.06-fold (95\%CI: 1.02-1.10) greater frequency of vaccination against hepatitis B than men. Dentists who reported the use of IPE had a 1.05-fold (95\%CI: 1.01-1.09) greater prevalence of vaccination. Dentists who reported having received no blood transfusions had a 1.10 -fold $(95 \% \mathrm{CI}$ : 1.01-1.21) greater prevalence of vaccination. Dentists reported having no combined risk factors had a 1.08 -fold (95\%CI: 1.02-1.15) greater prevalence of vaccination (Table 2).

When asked whether they knew their immunization status or had performed a post-vaccination test, $14.8 \%$ of the total sample reported having taken the test. Immunization status was associated with work experience $(\mathrm{p}=$ $0.003)$, the use of IPE $(p=0.003)$, dental care for patients with hepatitis $(\mathrm{p}=0.011)$, the custom of asking patients about hepatitis during dental treatment $(\mathrm{p}=0.001)$ and a family history of hepatitis $(\mathrm{p}=0.004)$ (Table 3$)$. The multivariate analysis revealed that dentists who reporting the use of IPE had a 1.03-fold (95\%CI: 1.00-1.07) greater prevalence of vaccination. Dentists who asked patients about hepatitis had a 1.07 -fold (95\%CI: 1.04-1.11) greater prevalence of immunization. Dentists who reported a family history of hepatitis had a 1.06 -fold $(95 \% \mathrm{CI}$ : 1.02 1.12) greater prevalence of immunization. Dentists with less than 10 years of experience had a 1.07 -fold $(95 \% \mathrm{CI}$ : 1.02-1.12) greater prevalence of immunization when compared to dentists with more than 30 years of experience. Dentists with 10 to 20 years of experience had a 1.07-fold (95\%CI: 1.02-1.13) greater prevalence of immunization when compared to dentists with more than 30 years of experience. There was no difference in the prevalence of immunization between those with 20 to 30 years of experience and those with more than 30 years of experience (Table 4).

\section{Discussion}

Prevention is ultimately the most efficient and humane means toward improved health [33]. Immunization programs are highly effective, clearly protect populations and individuals at risk and are leading to the elimination of hepatitis B [34]. Viral hepatitis is preventable with effective vaccines, which have been available since 1982 and have proven safe to both adults and children $[7,10]$. How- ever, despite being safe, efficacious and cost-effective, hepatitis $\mathrm{B}$ vaccination remains consistently underemployed [34].

Reports from different countries reveal that some dentists do not engage in safe practices, such as the use of gloves, facemasks or protective eyeglasses. Moreover, hepatitis B virus vaccination coverage is not complete among dentists, as reported for countries such as Nigeria, Jordan, Iran and the United Kingdom [17-23].

The results of the present study reveal that an average of $73.8 \%$ of the dentists had taken the three doses of the hepatitis B vaccine. The Brazilian Ministry of Health offers the National Viral Hepatitis Program, which has provided free vaccinations for newborn children, adolescents, those who work in the sex industry and healthcare workers since 1998. Thus, a higher number of vaccinated dentists was expected. However, this is a good coverage compared to countries that do not have government vaccination programs, such as Kenya, where only $12.8 \%$ of healthcare workers have been vaccinated for hepatitis B [23]. It is important to point out the differences between the two studies: The present study was carried out in a large city, whereas the Kenyan study was carried out in Thika, which is a typical small Kenyan district [23]. The number of vaccinated dentists in the present study was also higher than that reported for correctional healthcare workers in three American states, in which only $64 \%$ of the 411 professionals interviewed reported having received all three doses of the vaccine [35]. On the other hand, vaccination coverage among English dentists is quite higher than that reported in the present study [22].

Female dentists, dentists who use IPE and those who reported the use of illicit drugs had a greater prevalence of vaccination for hepatitis B. A study carried out in the city of Recife (Brazil) found that women adhere to infection control measures more than male dentists [36]. It is troubling that dentists who use illicit drugs and those with a history of blood transfusion have a lower proportion of adherence to the vaccination than those who do not report these factors, considering the increased risk [2]. On the other hand, it appears that the dentists who adhere more to infection control measures, such as the use of EPI, also have a higher prevalence of vaccination. This finding is similar to that reported in a study carried out in Iran [20].

Regarding vaccination status, there were no differences in relation to work experience. This may be explained by the fact that all the three dental schools in the city of Belo Horizonte offer an immunization program for their students before initiating dental practice, which explains why most of the dentists are vaccinated, especially those recently graduated. Those with a longer-standing profession may have been vaccinated during a campaign by the Dental Council of Minas Gerais in 1996, when all dentists 
Table 1: Factors associated with self-reporting of hepatitis B vaccination among Brazilian dentists, Belo Horizonte, 2005

\begin{tabular}{|c|c|c|c|c|}
\hline & \multicolumn{3}{|c|}{ Hepatitis B vaccination } & \multirow[t]{2}{*}{ p-value } \\
\hline & Yes & No & Total & \\
\hline \multicolumn{5}{|l|}{ Gender } \\
\hline Male & 288 & 71 & 359 & $0.003^{*}$ \\
\hline Female & 674 & 101 & 775 & \\
\hline Total & 962 & 172 & 1134 & \\
\hline \multicolumn{5}{|l|}{ Work experiencet† } \\
\hline Less than 10 years & 264 & 42 & 306 & $0.431 *$ \\
\hline $10-20$ years & 256 & 41 & 297 & \\
\hline 21 - 30 years & 319 & 51 & 370 & \\
\hline More than 30 years & 115 & 27 & 142 & \\
\hline Total & 954 & 161 & 1115 & \\
\hline \multicolumn{5}{|l|}{ Workplacet† } \\
\hline Public & 202 & 34 & 236 & $0.945^{*}$ \\
\hline Private & 408 & 72 & 480 & \\
\hline Both & 274 & 50 & 324 & \\
\hline Total & 884 & 156 & 1040 & \\
\hline \multicolumn{5}{|l|}{ Field t† } \\
\hline General dentistry & 409 & 52 & 461 & $0.067^{* *}$ \\
\hline Oral Surgery/Periodontology & 109 & 20 & 129 & \\
\hline Operative Dentistry/Endodontics & 131 & 27 & 158 & \\
\hline Paediatric Dentistry/Orthodontics & 112 & 26 & 138 & \\
\hline Oral Public Health & 38 & 4 & 42 & \\
\hline Oral Pathology/Oral Radiology & 18 & 6 & 24 & \\
\hline Total & 817 & 135 & 952 & \\
\hline \multicolumn{5}{|l|}{ Use of IPE } \\
\hline Yes & 631 & 91 & 722 & $0.001 *$ \\
\hline No & 331 & 81 & 412 & \\
\hline Total & 962 & 172 & 1134 & \\
\hline \multicolumn{5}{|l|}{ Needle stick accidentst† } \\
\hline Yes & 829 & 139 & 968 & $0.065^{*}$ \\
\hline No & 128 & 32 & 160 & \\
\hline Total & 957 & 171 & 1294 & \\
\hline \multicolumn{5}{|l|}{ Dental care for hepatitis patients $+\dagger$} \\
\hline Yes & 264 & 44 & 308 & $0.928^{*}$ \\
\hline No & 489 & 83 & 572 & \\
\hline Total & 753 & 127 & 880 & \\
\hline \multicolumn{5}{|l|}{ Question on patient history of hepatitis †† } \\
\hline Yes & 799 & 132 & 931 & $0.087^{*}$ \\
\hline No & 153 & 36 & 189 & \\
\hline Total & 952 & 168 & 1120 & \\
\hline
\end{tabular}




\begin{tabular}{|c|c|c|c|c|}
\hline \multicolumn{5}{|c|}{ Unprotected homo/hetero sext† } \\
\hline Yes & 202 & 37 & 239 & $0.862^{*}$ \\
\hline No & 752 & 133 & 885 & \\
\hline Total & 954 & 170 & 1124 & \\
\hline \multicolumn{5}{|c|}{ Blood transfusiont† } \\
\hline Yes & 42 & 16 & 58 & $0.006^{*}$ \\
\hline No & 881 & 147 & 1028 & \\
\hline Total & 923 & 163 & 1086 & \\
\hline \multicolumn{5}{|c|}{ Previous history of hepatitist† } \\
\hline Yes & 100 & 15 & 115 & $0.529^{*}$ \\
\hline No & 816 & 147 & 963 & \\
\hline Total & 916 & 162 & 1078 & \\
\hline \multicolumn{5}{|c|}{ Family history of hepatitis $\dagger^{\dagger}$} \\
\hline Yes & 227 & 34 & 261 & $0.387^{*}$ \\
\hline No & 521 & 94 & 615 & \\
\hline Total & 748 & 128 & 876 & \\
\hline \multicolumn{5}{|c|}{ Combined questiont, $+\dagger$} \\
\hline Yes & 106 & 29 & 135 & $0.026^{*}$ \\
\hline No & 829 & 137 & 966 & \\
\hline Total & 935 & 166 & 1101 & \\
\hline
\end{tabular}

in the state were offered free vaccinations. However, vaccination goes beyond taking vaccines; it implies a monitoring process, which is seldom considered including all vaccine series and over the lifetimes of individuals [33].

There was a very low prevalence of hepatitis B immunization. Studies carried out in Iran report that dentists take the test for the evaluation of immunization status with a frequency least 2.5-fold greater than Brazilian dentists [20,21]. This finding underscores the need for collective actions for raising the awareness of Brazilian dentists with regard to the evaluation of immunization status for this disease.

Dentists who adequately employ IPE, those who obtain a patient history regarding hepatitis $B$, those with a family history of hepatitis B and those more recently graduated had a greater frequency of self-reported immunization for hepatitis B. As mentioned above, dentists with a more favourable behaviour with regard to infection control measures are more apt to adhere to an immunization evaluation. Living with the disease in the family setting may have sensitized these dentists to adhering to every prevention protocol in the professional setting. Likewise, dentist who more recently graduated may have been sub-
Table 2: Adjusted factors associated with self-reporting of hepatitis B vaccination among Brazilian dentists, Belo Horizonte, 2005

Prevalence Ratio p-value
$(95 \% \mathrm{Cl})$

\begin{tabular}{lll}
$\begin{array}{l}\text { Gender } \\
\text { Female }\end{array}$ & $1.06(1.02-1.10)$ & 0.006 \\
Male & 1 & \\
\hline $\begin{array}{l}\text { Use of IPE } \\
\text { Yes }\end{array}$ & $1.05(1.01-1.09)$ & 0.021 \\
No & 1 & \\
\hline $\begin{array}{l}\text { Blood transfusion } \\
\text { No } \\
\text { Yes }\end{array}$ & $1.10(1.01-1.21)$ & 0.024 \\
\hline $\begin{array}{l}\text { Nombined question } \\
\text { Yes }\end{array}$ & 1 & \\
\hline
\end{tabular}


Table 3: Factors associated with self-reporting of hepatitis B post-vaccination test among Brazilian dentists, Belo Horizonte, 2005

\begin{tabular}{|c|c|c|c|c|}
\hline & \multicolumn{3}{|c|}{ Knowledge on immunization status } & \multirow[t]{2}{*}{ p-value } \\
\hline & Yes & No & Total & \\
\hline \multicolumn{5}{|l|}{ Gender } \\
\hline Male & 55 & 256 & 311 & $0.253^{*}$ \\
\hline Female & 138 & 525 & 663 & \\
\hline Total & 193 & 781 & 974 & \\
\hline \multicolumn{5}{|l|}{ Work experiencet† } \\
\hline Less than 10 years & 65 & 222 & 287 & $0.003^{*}$ \\
\hline $10-20$ years & 62 & 182 & 244 & \\
\hline $21-30$ years & 55 & 264 & 319 & \\
\hline More than 30 years & 11 & 99 & 110 & \\
\hline Total & 193 & 767 & 960 & \\
\hline \multicolumn{5}{|l|}{ Workplacet† } \\
\hline Public & 45 & 155 & 200 & $0.511^{*}$ \\
\hline Private & 76 & 332 & 408 & \\
\hline Both & 58 & 221 & 279 & \\
\hline Total & 179 & 708 & 887 & \\
\hline \multicolumn{5}{|l|}{ Fieldt+ } \\
\hline General dentistry & 72 & 328 & 400 & $0.085^{* *}$ \\
\hline Oral Surgery/Periodontology & 35 & 87 & 122 & \\
\hline Operative Dentistry/Endodontics & 21 & 104 & 125 & \\
\hline Paediatric Dentistry/Orthodontics & 27 & 98 & 125 & \\
\hline Oral Public Health & 4 & 26 & 30 & \\
\hline Oral Pathology/Oral Radiology & 5 & 11 & 16 & \\
\hline Total & 164 & 654 & 818 & \\
\hline \multicolumn{5}{|l|}{ Use of IPE } \\
\hline Yes & 142 & 484 & 626 & 0.003 \\
\hline No & 51 & 297 & 348 & \\
\hline Total & 193 & 781 & 974 & \\
\hline \multicolumn{5}{|l|}{ Needle stick accidentst† } \\
\hline Yes & 171 & 663 & 834 & 0.227 \\
\hline No & 22 & 115 & 137 & \\
\hline Total & 193 & 778 & 971 & \\
\hline \multicolumn{5}{|l|}{ Dental care for hepatitis patients $\dagger^{\dagger}$} \\
\hline Yes & 69 & 199 & 268 & 0.011 \\
\hline No & 89 & 406 & 495 & \\
\hline Total & 158 & 605 & 763 & \\
\hline
\end{tabular}


Table 3: Factors associated with self-reporting of hepatitis B post-vaccination test among Brazilian dentists, Belo Horizonte, 2005 (Continued)

\begin{tabular}{|c|c|c|c|c|}
\hline \multicolumn{5}{|c|}{ Question on patient history of hepatitis †† } \\
\hline Yes & 176 & 626 & 802 & 0.001 \\
\hline No & 17 & 144 & 161 & \\
\hline Total & 193 & 770 & 962 & \\
\hline \multicolumn{5}{|c|}{ Unprotected homo/hetero sext† } \\
\hline Yes & 37 & 157 & 194 & 0.790 \\
\hline No & 154 & 619 & 773 & \\
\hline Total & 191 & 776 & 967 & \\
\hline \multicolumn{5}{|c|}{ Blood transfusiont† } \\
\hline Yes & 7 & 40 & 47 & 0.393 \\
\hline No & 179 & 717 & 896 & \\
\hline Total & 186 & 757 & 943 & \\
\hline \multicolumn{5}{|c|}{ Previous history of hepatitist† } \\
\hline Yes & 23 & 77 & 100 & 0.459 \\
\hline No & 164 & 662 & 826 & \\
\hline Total & 187 & 739 & 926 & \\
\hline \multicolumn{5}{|c|}{ Family history of hepatitis †† } \\
\hline Yes & 61 & 164 & 225 & 0.004 \\
\hline No & 96 & 444 & 540 & \\
\hline Total & 157 & 608 & 765 & \\
\hline \multicolumn{5}{|c|}{ Combined questiont, $+\dagger$} \\
\hline Yes & 26 & 107 & 188 & 0.935 \\
\hline No & 162 & 654 & 761 & \\
\hline Total & 188 & 816 & 949 & \\
\hline
\end{tabular}

mitted to a different training/education process in relation to infection control measures. Further education may be appropriate in order to impress upon dental students and dentists alike the importance of knowledge on their own vaccination and immunization status.

The present study has some limitations that must be recognized. Cross-sectional studies are carried out either at a single point in time or over a short period. Thus, associations identified in cross-sectional studies should not be considered a causal relationship. However, there is a lack of studies that concomitantly assess the knowledge of dentists regarding their own hepatitis vaccination and immunization status, as we performed in the present study.

Given the huge burden of hepatitis B infection worldwide and the number of advances made in the past several decades, it is surprising that more progress in limiting the infection has not been made. Hepatitis $B$ continues to spread in endemic areas where universal vaccination has not yet been achieved. The availability of the vaccine and its use in preventing neonatal transmission as well as the increasing use of suppressive therapies should yield greater gains in the eradication of hepatitis $B$ in upcoming generations $[3,4]$. Moreover, dentists should 


\section{Table 4: Adjusted factors associated with self-relating of hepatitis B post-vaccination test among Brazilian dentists, Belo Horizonte, 2005}

\begin{tabular}{|c|c|c|}
\hline & $\begin{array}{l}\text { Prevalence Ratio } \\
(95 \% \mathrm{Cl})\end{array}$ & p-value \\
\hline \multicolumn{3}{|l|}{ Use of IPE } \\
\hline Yes & 1.03 (1.0-1.07) & 0.038 \\
\hline No & 1 & \\
\hline \multicolumn{3}{|l|}{$\begin{array}{l}\text { Question on patient } \\
\text { history of hepatitis }\end{array}$} \\
\hline Yes & $1.07(1.04-1.11)$ & $<0.001$ \\
\hline No & 1 & \\
\hline \multicolumn{3}{|l|}{$\begin{array}{l}\text { Family history of } \\
\text { hepatitis }\end{array}$} \\
\hline Yes & $1.06(1.02-1.10)$ & 0.003 \\
\hline No & 1 & \\
\hline \multicolumn{3}{|l|}{ Work experience } \\
\hline Less than 10 years & $1.07(1.02-1.12)$ & 0.004 \\
\hline $10-20$ years & $1.07(1.02-1.13)$ & 0.006 \\
\hline 21 - 30 years & $1.02(0.98-1.17)$ & 0.262 \\
\hline More than 30 years & 1 & \\
\hline
\end{tabular}

be better instructed with regard to the importance of compliance to the vaccination and taking the post-vaccination test in order to assist in the elimination of hepatitis B.

\section{Conclusions}

The prevalence of hepatitis B vaccination among Brazilian dentists was associated to gender, blood transfusion and risk behaviours. A low percentage of dentists reported having taken the post-vaccination test and few were aware of their immunization status. We strongly recommend that dentists, as a potential risk group, should know their immunization status so that those who require revaccination can obtain it.

\section{Competing interests}

The authors declare that they have no competing interests.

\section{Authors' contributions}

VLSR, MHGA, SMP, RT and IAP conceptualized the rationale and design of the study. VLSR and MHGA performed the statistical analysis and interpretation of the data. VLSR, MHGA, SMP and IAP drafted the manuscript. All authors read and approved the final manuscript.

\section{Acknowledgements}

The authors are grateful to the Dental Council of Minas Gerais, the State of Minas Gerais Research Foundation (FAPEMIG) and the National Council for Scientific and Technological Development (CNPq).

\section{Author Details}

1 Department of Operative Dentistry, Dental School, Federal University of Minas Gerais, Belo Horizonte, Brazil, 2Department of Community and Preventive Dentistry, Dental School, Federal University of Minas Gerais, Belo Horizonte, Brazil, 3Department of Paediatric Dentistry and Orthodontics, Dental School, Federal University of Minas Gerais, Belo Horizonte, Brazil and ${ }^{4}$ Department of Internal Medicine, Medical School, Federal University of Minas Gerais, Belo Horizonte, Brazil

Received: 1 May 2010 Accepted: 13 July 2010

Published: 13 July 2010

References

1. Ammon A, Reichart PA, Pauli G: Hepatitis B and C among Berlin dental personnel: incidence, risk factors, and effectiveness of barrier prevention measures. Epidemiol Infect 2000, 125:407-413.

2. François $G$, Hallauer J, Van Damme: Hepatitis B vaccination: how to reach risk groups. Vaccine 2002, 21:1-4.

3. Ocama P, Opio CK, Lee WM: Hepatitis B virus infection: current status. Am J Med 2005, 118:1413.

4. Ropero AM, Danovaro-Holliday MC, Andrus JK: Progress in vaccination against hepatitis B in the Americas. J Clin Virol 2005, 34:S14-S19.

5. Sharma SK, Saini N, Chwla Y: Hepatitis B virus: inactive carriers. Virol J 2005, 28:82

6. Odusanya OO, Meurice FP, Hoet B: Nigerian medical students are at risk for hepatitis B infection. Trans R Soc Trop Med Hyg 2007, 101:465-8.

7. Van Damme $P$, Van Herck K: A review of the long-term protection after hepatitis A and B vaccination. Travel Med Infect Dis 2007, 5:79-84.

8. Bertoletti A, Ferrari C: Kinetics of the immune response during $\mathrm{HBV}$ and HCV infection. Hepatology 2003, 38:4-13.

9. Xiao-wen H, Shu-han S, Zhen-lin H, Jun L, Lei J, Feng-juan Z, Ya-nan Z, Ying-jun G: Augmented humoral and cellular immune responses of a hepatitis B DNA vaccine encoding HbsAG by protein boosting. Vaccine 2005, 23:1649-56

10. WHO: World Health Organization Hepatitis C. Fact Sheets 2000 [http:// www.who.int/mediacentre/factsheets/en/]. Acessed December $18 \mathrm{~h}$, 2009

11. Fry DE: Occupational blood-borne diseases in surgery. Am J Surg 2005, 190:249-54.

12. Cottone JA, Puttaiah R: Hepatitis B virus infection. Current status in dentistry. Dent Clin North Am 1996, 40:293-307.

13. Deisenhammer S, Radon K, Nowak K, Reichert J: Needlestick injuries during medical training. J Hosp Infect 2006, 63:263-7

14. Fitzsimons D, François G, Hall A, McMahon B, Meheus A, Zanetti A, Duval B, Jilg W, Böcher WO, Lu SN, Akarca U, Lavanchy D, Goldstein S, Banatvala J, Damme PV: Long-term efficacy of hepatitis B vaccine, booster policy, and impact of hepatitis B virus mutants. Vaccine 2005, 22:4158-66.

15. Abe M, Abkar SM, Onji M: Zinc and hepatitis B virus immunization. Hepatol Res 2006, 35:1-2

16. Wang C, Tang J, Song W, Lobashevsky E, Wilson CM, Kaslow RA: HLA and cytokine gene polymorphisms are independently associate with responses to hepatitis B vaccination. Hepatology 2004, 39:978-88.

17. Sofola OO, Ui OG: Hepatitis B virus infection and prevention in the dental clinic: knowledge and factors determining vaccine uptake in a Nigerian dental teaching hospital. Nig Q J Hosp Med 2008, 18:145-8.

18. Uotomi IL: Attitudes of Nigerian dentists towards hepatitis B vaccination and use of barrier techniques. West Afr J Med 2005 , 24:223-6.

19. Al Negrish A, Al Momani AS, Al Sharafat F: Compliance of Jordanian dentists with infection control strategies. Int Dent J 2008, 58:231-6.

20. Alavian SM, Akbari H, Ahmadzad-Asl M, Kazem M, Dvoudi A, Tavangar H: Concerns regarding dentist's compliance in hepatitis $B$ vaccination and infection control. Am J Infect Control 2005, 33:428-9.

21. Alavian SM, Izadi M, Zare AA, Lankarani MM, Assari S, Vardi MM: Survey of the level of anti-HBs antibody titer in vaccinated Iranian genera dentists. Spec Care Dentist 2008, 28:265-70.

22. Rhodes A, Aw TC, Allen C, Ridout M: Immunization status of dental practice staff in Kent. BrDent J 2008, 205:E20.

23. Suckling RM, Taegtmeyer M, Nguku PM, Al-Abri SS, Kibaru J, Chakaya JM, Tukei PM, Gilks CF: Susceptibility of healthcare workers in Kenya to hepatitis B: new strategies for facilitating vaccination uptake. J Hosp Infect 2006, 64:271-7. 
24. Batista SM, Andreasi MS, Borges AM, Lindberg AS, Silva AL, Fernandes TD, Pereira EF, Basmage EA, Cardoso DD: Soropositivity for hepatitis B vírus vaccination coverage, and vaccine response in dentists from Campo Grande, Mato Grosso do Sul, Brazil. Mem Inst Oswaldo Cruz 2006 101:263-7.

25. Dean AG, Dean JA, Coulombier D, Burton AH, Brendei KA, Smith DC: Epi Info ${ }^{\mathrm{TM}}$, Version 6.04a, a word processing, database, and statistics program for public health on IBM-compatible microcomputers Atlanta: Centers for Disease Control and Prevention; 1996.

26. Resende VLS, Abreu MHG, Paiva SM, Teixeira R, Pordeus IA: Factors associated with seroprevalence of hepatitis $\mathrm{C}$ among dentists of a large Brazilian city. Virology J 2009, 6:228.

27. Streiner DL, Norman GL: Health measurements scales: a practical guide to their development and use 2nd edition. Oxford: Oxford University; 2005.

28. Machado-Carvalhais HP, Ramos-Jorge ML, Auad SM, Martins LH, Paiva SM, Pordeus IA: Occupational exposure to potentially infectious biological material in dental teaching environment. J Dent Educ 2008, 72:1201-8.

29. Araujo MW, Andreana S: Risk and prevention of transmission of infectious diseases in dentistry. Quintessence Int 2002, 33:376-82.

30. Porter S, Scully C, Samaranayake L: Viral Hepatitis: Current concepts for dental practice. Oral Surg Oral Med Oral Pathol 1994, 78:682-95.

31. Lodi G, Porter SR, Teo CG, Scully C: Prevalence of HCV infection in healthcare workers of UK dental hospital. Br Dent J 1997, 183:329-32.

32. Sofola OO, Savage KO: Assessment of the compliance of Nigerian dentists with infection control: a preliminary study. Infec Cont Hosp Epidemiol 2003, 24:737-40.

33. Ehreth J: The value of vaccination: a global perspective. Vaccine 2003 , 21:4105-17

34. Mast EE, Margolis HS, Fiore AE, Brink EW, Goldstein ST, Wang SA, Moyer LA, Bell BP, Alter MJ, Advisory Committee on Immunization Practices (ACIP): A comprehensive immunization strategy to eliminate transmission of hepatitis B virus infection in the United States: recommendations of the Advisory Committee on Immunization Practices (ACIP) part 1 : immunization of infants, children, and adolescents. MMWR Recomm Rep 2005, 54:1-31.

35. Gershon RR, Mitchell C, Sherman MF, Vlahov D, Lears MK, Felknor S, Lubelczyk RA: Hepatitis B vaccination in correctional health care workers. Am J Infect Control 2005, 33:510-8.

36. Brêda-Albuquerque F, de Farias AB, do Prado MG, Orestes-Cardoso S: Influence of clinicians' socio-demographic, professional and educational variables on their compliance with preventive measures against hepatitis B and C. Oral Health Prev Dent 2008, 6:349-54.

doi: $10.1186 / 1743-422 X-7-154$

Cite this article as: Resende et al., Concerns regarding hepatitis B vaccination and post-vaccination test among Brazilian dentists Virology Journal 2010, 7:154

Submit your next manuscript to BioMed Centra and take full advantage of:

- Convenient online submission

- Thorough peer review

- No space constraints or color figure charges

- Immediate publication on acceptance

- Inclusion in PubMed, CAS, Scopus and Google Scholar

- Research which is freely available for redistribution

Submit your manuscript at www.biomedcentral.com/submit
C Biomed Central 